\title{
Diversity and conservation of leaf cutter bees (Hymenoptera: megachilidae)
}

\begin{abstract}
Plants pollination is an important ecosystem service provided by insects to mankind. Among insects, hymenopterans are considered as efficient pollinators of several cultivated and uncultivated plant species. The leafcutter bees in the family Megachilidae are one of the important pollinators of many agricultural, horticultural, medicinal and aromatic crops. These bees being important pollinators of many wild plant species also play an important role in maintenance of the ecosystem. In this context, conservation of pollinators has emerged as a major issue. One of the conservation strategies is to place hollow reeds of Ipomoea carnea Jacq. For trap nesting leaf-cutter bees.
\end{abstract}

Keywords: nestin, abundance, floral association, biology, traps, pollination, pollen, nectar, megachilids, non-Apis bees
Volume 8 Issue I - 2018

\author{
Veeresh kumar,' Kumaranag KM² \\ 'ICAR-Central Agro Forestry Research Institute, India \\ 2Division of Entomology, Indian Agricultural Research Institute \\ (IARI), India
}

\author{
Correspondence: Veeresh kumar, ICAR-Central Agro \\ Forestry Research Institute, Jhansi, UP, India \\ Email veeresh4279@gmail.com
}

Received: December II, 2017| Published: February 07, 2018

\section{Introduction}

More than one-third of the world's crops require pollination to set seeds and fruits Dias et al. ${ }^{1}$ It is likely that wild bee community is sufficient to provide services for multiple crops, including some that are not serviced by honeybees Kremen et al. ${ }^{2}$ Under several situations nonApis bees are better pollinators than Apis species because of efficient tripping, fast foraging rate, longer tongue length, buzz pollination and oligo leptic foraging. Among non-Apis bees, Megachilidae is the second largest family next to Apidae with respect to the number of species. They play an important role in pollination of many cultivated and wild plants Veeresh Kumar. ${ }^{3,4}$ Many plants provide abundant and diverse pollen and nectar to support these bees in their habitat. Activity of these bees depends on the availability of resources and nesting sites in a habitat. There is a decline in the pollinator population in the past few decades due to drought, fire, habitat fragmentation, destruction of natural habitats, and tremendous use of pesticides generating great threats to the production of crops, thus leading to a food crisis. In this context, conservation of pollinators has emerged as a major issue. In order to formulate effective conservation strategies there is a need to generate information on diversity, abundance, associated flowering plants to fulfill the need of conservation planning.

\section{Discussion}

\section{Diversity and abundance}

Diversity is one of the most fundamental attributes of a biological community and its characterization is a basic requirement for studying or managing a system. There are 81 general, 237 subgenera with 4111 species in the family Megachilidae in the world Ascher et al. ${ }^{5}$ From India, Bingham ${ }^{6}$ reported 53 species under 8 genera, Gupta ${ }^{7}$ reported 25 genera with 225 species, and Ascher et al., ${ }^{5}$ reported 28 genera with 237 species. A study was conducted at University of Agricultural Sciences, Bangalore to estimate the leaf cutter bees species diversity and associated host plants, collection was made in different agro climatic regions of Karnataka during 2013-15 Veereshkumar et al. ${ }^{3}$ Veeresh Kumar. ${ }^{8}$ The study documents four tribes, 11 genera, 20 subgenera and 50 species of Megachilidae. Species diversity, their abundance and richness was more in dry zones compared to the remaining zones (Figure 1). In general, leaf cutter bees were found to be more abundant during June, July, September and October and moderately abundant during May, August, November and December and lowest during January to April. Rank abundance of different species of leaf cutter bees indicated that Megachile lanata was more abundant (27.01\%), followed by M. lerma (14.06\%), M. disjuncta (13.39\%), M. anthracina (8.93\%), Lithurgus atratus (5.13\%) and M. bicolor (4.46\%) (Figure 2).

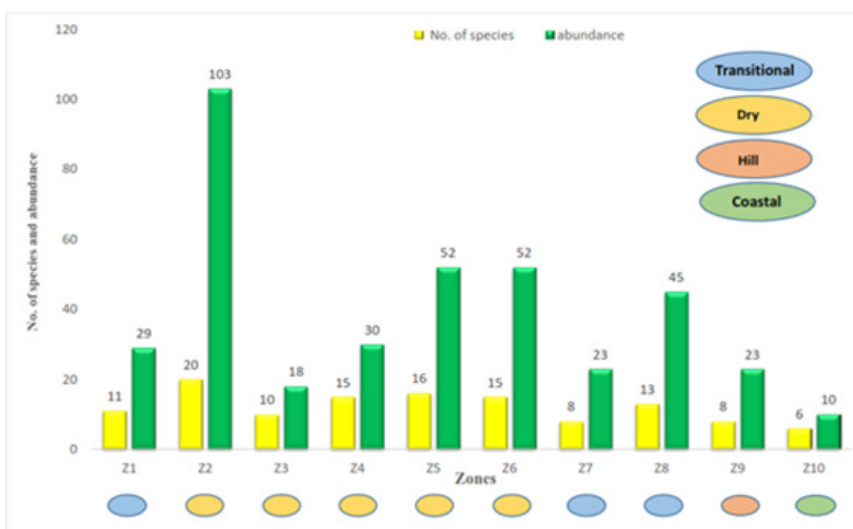

Figure I Leaf cutter bee species diversity and abundance in different agroclimatic zones Karnataka during 20I3-15

\section{Nesting}

Megachilids are commonly called as leaf cutters, wood borers, mason bees and cuckoo bees. Unlike honey bees, megachilids do not construct their hives with bee wax but make their own nests by using leaves to make nests for brood cells. Female gathers pollen and nectar, stores enough in the cell to feed larvae that will hatch from the egg she lays there. Sequence of nesting behaviour includes searching for nesting site, nest site inspection, cleaning of nest site, leaf gathering, pollen/nectar gathering, egg laying, leaf gathering and cell sealing.

\section{Host association}

Forty-four species of flowering plants belonging to 18 families were recorded as associated with these bees. This suggests the importance of pollinator conservation for the ecosystem functioning and also to maintain biological diversity. 

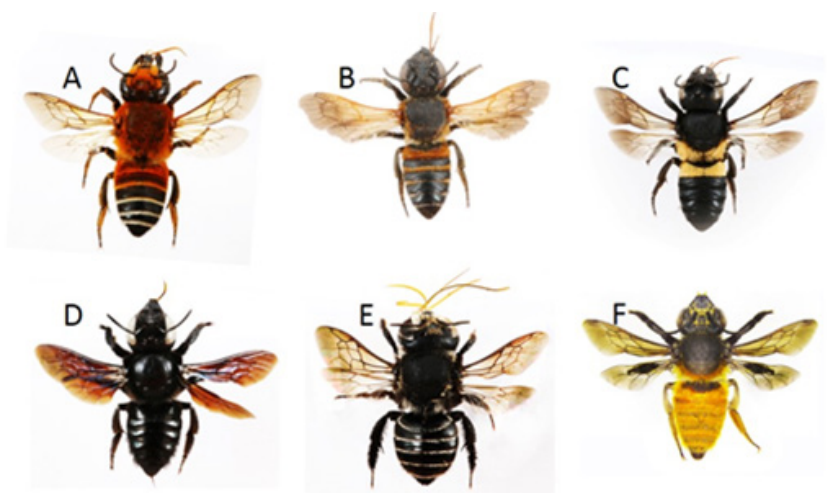

Figure 2 Abundant leaf cutter bee species; A- M. lanata, B- M. lerma, C- M. disjuncta, D-M. anthracina, E- L. atratus \& F-M. bicolor.

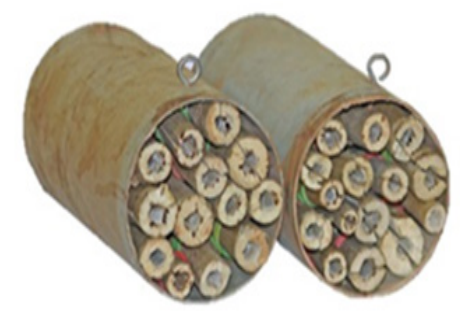

Figure 3 Reeds of Ipomea cornea used for trap nesting Veereshkumar et al. ${ }^{8}$

\section{Conservation strategies}

Farmers can follow some simple practices to make their farms and surrounding landscapes more suitable for bee pollinators. Some of the strategies are, encourage flowering plants to provide blooms through the growing season; minimize insecticide use, avoid spraying during bloom, and switch to more bee-friendly pesticides; for a more advanced approach, holes drilled into wooden blocks or bundles of cut plant stems can provide the necessary nesting sites that cavity nesting bees require; place hollow reeds of Ipomoea carnea Jacq. Figure 3 For trap nesting leaf-cutter bees as used by Veereshkumar et al. ${ }^{9}$

\section{Conclusion}

Adopting these strategies will conserve leaf cutter bees that will contribute to crop pollination. Enhancing the suitability of farm landscapes for native bees will also provide a diversified strategy for achieving good crop yields in pollination-dependent crops.

\section{Acknowledgements}

None.

\section{Conflict of interest}

The authors declare that they have no conflict of interest.

\section{References}

1. Dias BSF, Raw A, Imperatri-Fonseca VL. Report on the recommendations of the workshop on the conservation and sustainable use of pollinators in agriculture with emphasis on bees. Braz Min Env. 1999. p. 1-79.

2. Kremen C, Williams NM, Thorp RW. Crop pollination from native bees at risk from agricultural intensification. Proc Natl Acad Sci. 2002;99(26):16812-16816.

3. Veeresh Kumar. Taxonomic studies on leaf cutter bees (Hymenoptera: Megachilidae) of Karnataka. Ph.D. Thesis, Department of Entomology, Bangalore, Karnataka, India: University of Agricultural Sciences; 2015. p. $1-315$.

4. Veeresh Kumar, Uthappa AR, Madhulika Srivastava, et al. Floral biology of Grewia flavescens Juss.: an underutilized crop. Genetic Resources and Crop Evolution. 2017;64(7):1789-1795.

5. Ascher JS, Pickering J. Discover Life's bee species guide and world checklist; 2015.

6. Bingham CT. Fauna of British India. Hymenoptera- bees and wasps. Edi Taylor and Francis; $1975.579 \mathrm{p}$.

7. Gupta RK. The diversity of bees (Hymenoptera: Apoidea) in India. Adv. In Insect Biodiver. Agribios, Jodhpur, India; 2003.

8. Veereshkumar, Belavadi VV. The Buzz of the 'Other 'Bees: Species Diversity of Leaf Cutter Cees (Hymenoptera: Megachilidae) in Karnataka. Mysore J Agric Sci. 2015;49(2):332-336.

9. Veereshkumar, Belavadi VV, Ankita Gupta. Parasitisation of leaf-cutter bees (Megachilidae: Apoidea) by Melittobia. Entomon. 2015;40(2):105112 . 